Check for updates

Cite this: New J. Chem., 2018, 42, 12098

Received 8th March 2018, Accepted 19th June 2018

DOI: $10.1039 / c 8 n j 01077 c$

rsc.li/njc

\section{Two new hexanuclear titanium oxo cluster types and their structural connection to known clusters $\dagger$}

\author{
Matthias Czakler, Christine Artner and Ulrich Schubert (D)* \\ $\mathrm{Ti}_{6} \mathrm{O}_{6}(\mathrm{OiPr})_{2}\left(\mathrm{OOCR}^{\prime}\right)_{10}\left(\mathrm{R}^{\prime}=\mathrm{C}_{4} \mathrm{H}_{7}, \mathrm{Et}\right)$ and $\mathrm{Ti}_{6} \mathrm{O}_{3}(\mathrm{OiPr})_{14}(\mathrm{OOC}-\mathrm{CH}=\mathrm{CH}-\mathrm{COO})_{2}$ represent new structure \\ types of carboxylate-substituted clusters with $a \mathrm{Ti}_{6} \mathrm{O}_{x}$ core $(x=3-6)$. They complement the already \\ known six structure types and thus allow conclusions on how the structures of such clusters evolve \\ during substitution and condensation processes.
}

\section{Introduction}

Reaction of $\mathrm{Ti}(\mathrm{OR})_{4}$ with carboxylic acids results in the formation of carboxylate-substituted oxo clusters with a broad range of nuclearities. In such reactions, partial or complete substitution of the OR groups by carboxylate ligands and generation of oxo groups through ester formation between the carboxylic acid and the eliminated alcohol compete with each other. ${ }^{1,2}$ The degree of substitution $\left(d_{\mathrm{s}}=\mathrm{RCOO} / \mathrm{Ti}\right.$ ratio $)$ and the degree of condensation $\left(d_{\mathrm{c}}=\mathrm{O} / \mathrm{Ti}\right.$ ratio $)$ of the obtained clusters reflect the proportion of both reactions; they are key parameters for which structures are formed. In the case of titanium, $\mu_{3}-\mathrm{O}$ count for full for the calculation of $d_{\mathrm{c}}, \mu_{2}-\mathrm{O}$ for $2 / 3$ and $\mu_{4}-\mathrm{O}$ for $4 / 3$, because in rutile and anatase $\left(d_{\mathrm{c}}=2\right)$ every oxygen is $\mu_{3}-\mathrm{O}$.

Common to all $\mathrm{Ti}$ oxo clusters is that the $\mathrm{Ti}$ atoms are sixcoordinate (rarely five-coordinate, see below) and the carboxylate ligands almost always bridge two Ti atoms. Stable clusters are obtained if the metal charges are balanced by the ligands and all available coordination sites are occupied. A large percentage of (the uncharged) carboxylate-substituted titanium oxo clusters are hexanuclear where the six octahedrally coordinated Ti atoms sum up to 24 positive charges and 36 coordination sites in total. The cluster cores of the known $\mathrm{Ti}_{6}$ clusters are schematically shown in Scheme 1 . The $\mathrm{Ti}_{6}$ cluster type with the highest $d_{\mathrm{c}}$ (and a wide variety of $\mathrm{R} / \mathrm{R}^{\prime}$ combinations) is $\mathrm{Ti}_{6} \mathrm{O}_{6}(\mathrm{OR})_{6}\left(\mathrm{OOCR}^{\prime}\right)_{6}{ }^{3-18}$ where all oxygen atoms are $\mu_{3}-\mathrm{O}$. This leaves 12 positive charges unbalanced and 18 coordination sites unoccupied which are compensated by 6 terminal OR (one per Ti) and 6 bridging carboxylate ligands.

Institute of Materials Chemistry, Technische Universität Wien, Getreidemarkt 9, 1060 Wien, Austria.E-mail: Ulrich.Schubert@tuwien.ac.at

$\dagger$ CCDC 1826634 (1a), 1826635 (1b) and 1826636 (2). For crystallographic data in CIF or other electronic format see DOI: 10.1039/c8nj01077c

\$ This article is dedicated to Professor Dietmar Stalke on the occasion of his 60th birthday.
The robustness of the $\mathrm{Ti}_{6} \mathrm{O}_{6}(\mathrm{OR})_{6}\left(\mathrm{OOCR}^{\prime}\right)_{6}$ structure type is also demonstrated by the fact that the structures of many mixed-metal clusters are derived from this lead structure. ${ }^{19}$

The four cluster types with a $\mathrm{Ti}_{6} \mathrm{O}_{4}$ core vary by different $d_{\mathrm{S}}$ and $d_{\mathrm{c}} \cdot \mathrm{Ti}_{6} \mathrm{O}_{4}(\mathrm{OR})_{8}\left(\mathrm{OOCR}^{\prime}\right)_{8}{ }^{20-27}$ is the second most common $\mathrm{Ti}_{6}$ cluster type, with a higher $d_{\mathrm{s}}$ and a lower $d_{\mathrm{c}}$ than $\mathrm{Ti}_{6} \mathrm{O}_{6}(\mathrm{OR})_{6}\left(\mathrm{OOCR}^{\prime}\right)_{6}$. The two types of $\mathrm{Ti}_{6} \mathrm{O}_{4}(\mathrm{OR})_{12}\left(\mathrm{OOCR}^{\prime}\right)_{4}$ clusters are only represented by a few examples. ${ }^{28-31}$ The different proportion of terminal, $\mu_{2}$ and $\mu_{3}$ ligands $\left(\mu_{4}-\mathrm{O}\right.$ in $\mathrm{Ti}_{6} \mathrm{O}_{4}(\mathrm{OEt})_{14}(\mathrm{OOCPh})_{2}{ }^{32}$ is a very rare exception) in the $\mathrm{Ti}_{6} \mathrm{O}_{4}$ clusters results in different structures, i.e. in a different linkage of the $\left[\mathrm{TiO}_{6}\right]$ octahedra. There is only one example for a cluster with a $\mathrm{Ti}_{6} \mathrm{O}_{5}$ core, $\mathrm{Ti}_{6} \mathrm{O}_{5}(\mathrm{OiBu})_{6}(\mathrm{OOC} t \mathrm{Bu})_{8}{ }^{16}{ }^{16}$ which is structurally derived from the $\mathrm{Ti}_{6} \mathrm{O}_{4}(\mathrm{OR})_{8}(\mathrm{OOCR})_{8}$ structure by the (formal) replacement of two terminal OR groups by a $\mu_{2}-\mathrm{O}$. The $\mathrm{Ti}_{6} \mathrm{O}_{4}$ and $\mathrm{Ti}_{6} \mathrm{O}_{5}$ clusters can be considered structural intermediates on the way to $\mathrm{Ti}_{6} \mathrm{O}_{6}$ clusters, with pre-formed elements of the $\mathrm{Ti}_{6} \mathrm{O}_{6}$ structure. The conversion into the corresponding $\mathrm{Ti}_{6} \mathrm{O}_{6}(\mathrm{OR})_{6}\left(\mathrm{OOCR}^{\prime}\right)_{6}$ cluster was proven experimentally in two cases, namely for $\mathrm{Ti}_{6} \mathrm{O}_{4}(\mathrm{OEt})_{8}(\mathrm{OOCMe})_{8}{ }^{3}$ and $\mathrm{Ti}_{6} \mathrm{O}_{5}(\mathrm{OiBu})_{6}(\mathrm{OOC} t \mathrm{Bu})_{8} \cdot{ }^{16}$ The occurrence of $\mathrm{Ti}_{3}\left(\mu_{3}-\mathrm{O}\right)$ units in nearly all Ti oxo clusters, also in clusters with low $d_{\mathrm{c}}$, is a strong indication that this unit is formed in an early stage of the condensation process.

In this article, we report two new structure types of $\mathrm{Ti}_{6}$ oxo clusters (Scheme 2), which demonstrate the structural variability of this cluster class, depending on $d_{\mathrm{s}}$ and $d_{\mathrm{c}}$, but nevertheless have some features in common and thus complement the series of clusters shown in Scheme 1. Both contain $\mathrm{Ti}_{3}\left(\mu_{3}-\mathrm{O}\right)$ units as building blocks. As we have pointed out earlier (in an article on $\mathrm{Ti}_{3} \mathrm{O}(\mathrm{OR})_{8}\left(\mathrm{OOCR}^{\prime}\right)_{2}$ clusters $\left.{ }^{33}\right)$ that the $\mathrm{Ti}_{3} \mathrm{O}$ unit can be flat or pyramidal, without obvious correlation to other structural parameters. This possibly indicates that flat/pyramidal conversion is easy. To facilitate the comparison between the different cluster 
<smiles></smiles>
$\mathrm{Ti}_{6} \mathrm{O}_{4}(\mathrm{OR})_{8}(\mathrm{OOCR})_{8}$

$d_{\mathrm{s}}=1.33$

$d_{c}=0.56$

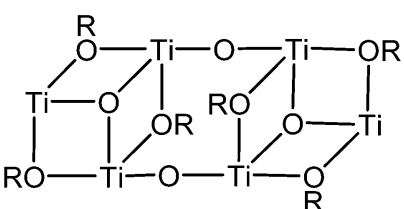

$\mathrm{Ti}_{6} \mathrm{O}_{4}(\mathrm{OR})_{12}\left(\mathrm{OOCR}^{\prime}\right)_{4}$ (type I)

$d_{\mathrm{S}}=0.67$

$d_{\mathrm{c}}=0.56$

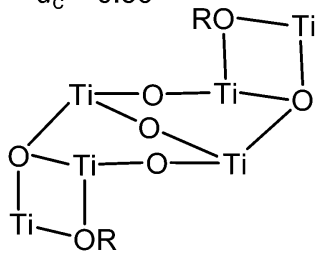

$\mathrm{Ti}_{6} \mathrm{O}_{5}(\mathrm{OR})_{6}(\mathrm{OOCR})_{8}$

$d_{\mathrm{s}}=1.33$

$d_{\mathrm{c}}=0.66$

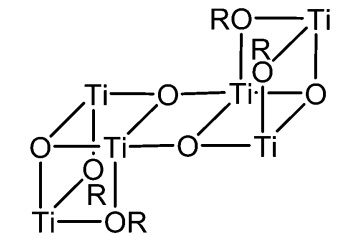

$\mathrm{Ti}_{6} \mathrm{O}_{4}(\mathrm{OR})_{12}\left(\mathrm{OOCR}^{\prime}\right)_{4}$ (type II)

$$
d_{\mathrm{s}}=0.67
$$$$
d_{\mathrm{c}}=0.67
$$

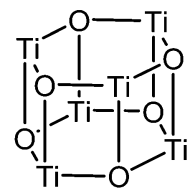

$\mathrm{Ti}_{6} \mathrm{O}_{6}(\mathrm{OR})_{6}(\mathrm{OOCR})_{6}$ $d_{\mathrm{s}}=1$ $d_{\mathrm{c}}=1$

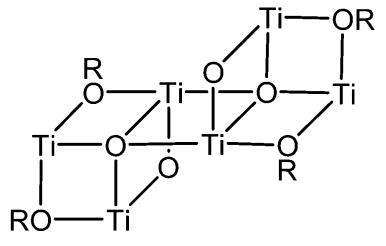

$\mathrm{Ti}_{6} \mathrm{O}_{4}(\mathrm{OR})_{14}\left(\mathrm{OOCR}^{\prime}\right)_{2}$

$d_{\mathrm{s}}=0.33$

$d_{\mathrm{c}}=0.67$

Scheme 1 Schematic structures of the cluster cores of known carboxylate-substituted $\mathrm{Ti}_{6} \mathrm{O}_{x}$ clusters. Terminal OR ligands and (always bridging) carboxylate ligands were omitted. The conformation of the cluster cores are drawn to emphasize structural similarities between them.<smiles></smiles>

$$
\begin{gathered}
\mathrm{Ti}_{6} \mathrm{O}_{6}(\mathrm{OR})_{2}\left(\mathrm{OOCR}^{\prime}\right)_{10} \\
d_{\mathrm{s}}=1.67 \\
d_{\mathrm{c}}=0.78
\end{gathered}
$$

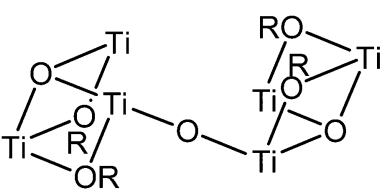

$$
\begin{gathered}
\mathrm{Ti}_{6} \mathrm{O}_{3}(\mathrm{OR})_{14}(\mathrm{OOCR})_{4} \\
d_{\mathrm{S}}=0.67 \\
d_{\mathrm{c}}=0.44
\end{gathered}
$$

Scheme 2 Schematic core structures of the new cluster reported in this article. Terminal OR ligands and carboxylate ligands were omitted. The conformation of the cluster cores are drawn to emphasize structural similarities to the clusters in Scheme 1.

structures we have drawn the $\mathrm{Ti}_{3} \mathrm{O}$ units in Scheme 2, and all other Schemes in this article, in pyramidal conformations.

\section{Results}

Reaction of $\mathrm{Ti}(\mathrm{OiPr})_{4}$ with 4 molar equivalents of cyclobutane carboxylic acid resulted in the formation of $\mathrm{Ti}_{6} \mathrm{O}_{6}(\mathrm{OiPr})_{2}-$ $\left(\mathrm{OOCC}_{4} \mathrm{H}_{7}\right)_{10}$ (1a, Fig. 1). An isostructural cluster, $\mathrm{Ti}_{6} \mathrm{O}_{6}(\mathrm{OiPr})_{2}-$ (OOCEt) $)_{10}(\mathbf{1 b})$ was obtained as a minor side-product in a different reaction, which shows that 1a is not an isolated case. There are no significant structural differences between 1a and $\mathbf{1 b}$. The centrosymmetric structures consist of six roughly coplanar titanium atoms. Two $\mathrm{Ti}_{3} \mathrm{O}$ units, with nearly trigonalplanar $\mu_{3}-\mathrm{O}$ atoms (sum of angles $354.6^{\circ}$ ), are bridged by two $\mu_{2}-\mathrm{O}$ and four carboxylate ligands. The Ti/O core structure is basically the same as that of the $\mathrm{Ti}_{6} \mathrm{O}_{4}(\mathrm{OR})_{8}\left(\mathrm{OOCR}^{\prime}\right)_{8}$ clusters (Scheme 1), but the two bridging OR groups in the $\mathrm{Ti}_{6} \mathrm{O}_{4}$ clusters are replaced by $\mu_{2}-\mathrm{O}$ atoms. This replacement, however,

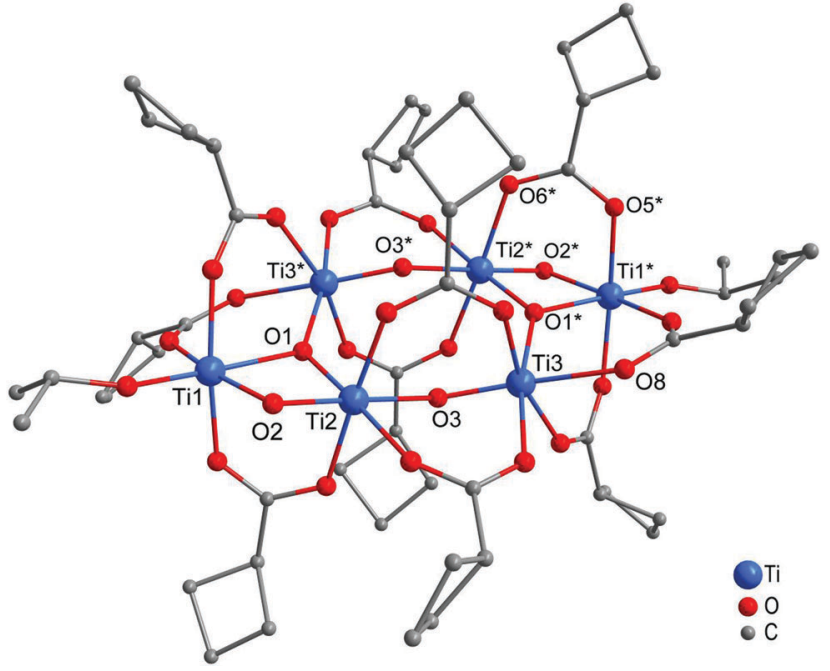

Fig. 1 Molecular structure of $\mathrm{Ti}_{6} \mathrm{O}_{6}(\mathrm{OiPr})_{2}\left(\mathrm{OOCC}_{4} \mathrm{H}_{7}\right)_{10}$ (1a). Hydrogen atoms were omitted for clarity. Selected bond distances $[\AA]$ and angles []: Ti1-O1 2.093(3), Ti2-O1 1.867(3), Ti3-O1 1.918(3), Ti1-O2 1.837(3), $\mathrm{Ti} 2-\mathrm{O} 2$ 1.810(3), Ti2-O3 2.003(3), Ti3-O3 1.722(3). Ti2-O1-Ti3* 133.0(2), Ti2-O1-Ti1 91.9(1), Ti3-O1-Ti1 129.6(2), Ti2-O2-Ti1 102.8(2), Ti3-O3-Ti2 131.8(2).

also affects the bystander ligands, because the Ti charges must be balanced and all coordination sites occupied. To keep the cluster uncharged, two additional singly charged ligands (OR) must be removed, which, however, leaves two coordination sites unoccupied. Therefore two further terminal (OR) groups must be replaced by two bridging (carboxylate) ligands.

For this reason, the arrangement of ligands decorating the $\mathrm{Ti}_{6} \mathrm{O}_{6}$ cluster core in $\mathbf{1}$ is slightly different compared to $\mathrm{Ti}_{6} \mathrm{O}_{4}(\mathrm{OR})_{8}\left(\mathrm{OOCR}^{\prime}\right)_{8}$. Only the outer Ti atoms (Ti1 and symmetryrelated Ti1* in 1a) of the ellipse-shaped $\mathrm{Ti}_{6}$ arrangement still carry 
a terminal OiPr group (these atoms are substituted by two terminal OR ligands in the $\mathrm{Ti}_{6} \mathrm{O}_{4}$ clusters). All the other coordination sites are occupied by oxygen atoms of bridging carboxylate ligands. Thus, Ti1 and Ti2 are coordinated by three bridging carboxylate ligands, and Ti3 by four. This results in the highest $d_{\mathrm{s}}$ among all the $\mathrm{Ti}_{6}$ oxo clusters. In passing, the highest possible $d_{\mathrm{s}}$ for $\mathrm{Ti}$ oxo clusters (with 6-coordinate $\mathrm{Ti}$ atoms) is 2 as in $\left[\mathrm{TiO}\left(\mathrm{OOCR}^{\prime}\right)_{2}\right]_{8} \cdot{ }^{34}$

The $\mathrm{Ti}_{3} \mathrm{O}$ group in $\mathbf{1}$ is quite unsymmetrical, the Ti1-O1 distance being much longer than Ti2-O1 and Ti3-O1 and, correspondingly, Ti2-O1-Ti3* being much larger than Ti2-O1-Ti1 and Ti3-O1-Ti1. This distortion of the $\mathrm{Ti}_{3} \mathrm{O}$ group is also observed in the $\mathrm{Ti}_{6} \mathrm{O}_{4}(\mathrm{OR})_{8}\left(\mathrm{OOCR}^{\prime}\right)_{8}$ clusters and possibly due to the terminal OR group being trans to Ti1-O1 (for example in $\mathrm{Ti}_{6} \mathrm{O}_{4}(\mathrm{OEt})_{8}\left(\mathrm{OOC}-\mathrm{CMe}=\mathrm{CH}_{2}\right)_{8}$ : Ti-O 1.895(4), 1.895(5), 2.093(3); Ti-O-Ti 129.4(2), 128.2(2), 101.9(2) $\left.{ }^{23}\right)$.

The main difference in the core structures of $\mathbf{1}$ and $\mathrm{Ti}_{6} \mathrm{O}_{4}(\mathrm{OR})_{8}\left(\mathrm{OOCR}^{\prime}\right)_{8}$, resulting from the replacement of a $\mu_{2}$-OR by a $\mu_{2}-\mathrm{O}$ in the $\mathrm{Ti}_{3} \mathrm{O}$ unit, is the position of the oxygen atoms bridging the two $\mathrm{Ti}_{3} \mathrm{O}$ entities. This oxygen (O3 and $\mathrm{O}_{3}^{*}$ in 1a) is trans to another bridging oxygen $(\mathrm{O} 2$, which is essentially symmetrically located between $\mathrm{Ti} 1$ and $\mathrm{Ti} 2)$ at $\mathrm{Ti} 2$ in 1a, but trans to a bridging OR group in $\mathrm{Ti}_{6} \mathrm{O}_{4}(\mathrm{OR})_{8}\left(\mathrm{OOCR}^{\prime}\right)_{8}$. While $\mathrm{O} 3$ in 1a is shifted away from Ti2 [Ti2-O3 2.003(3), Ti3-O3 1.722(3) $\mathrm{A}]$, the oxygen bridging the two $\mathrm{Ti}_{3} \mathrm{O}$ entities in $\mathrm{Ti}_{6} \mathrm{O}_{4}(\mathrm{OR})_{8}\left(\mathrm{OOCR}^{\prime}\right)_{8}$ is shifted towards the respective Ti atom (with a smaller difference between both Ti-O distances). This is apparently due to a different trans influence of $\mu_{2}-\mathrm{O}$ compared with $\mu_{2}$-OR. The pronounced asymmetry of the Ti2-O3-Ti3 arrangement in 1a also affects bonding of the carboxylate ligand bridging Ti1 and Ti3*, where Ti1-O7 (2.010(4) ̊) is shorter and Ti3-O8 (2.152(3) Å) much longer than the other carboxylate Ti-O distances $(2.010(4)-2.063(3) \AA$ ).

The situation in solution is hard to comprehend, because the number of signals of $1 \mathrm{a}$ in both the ${ }^{1} \mathrm{H}$ and ${ }^{13} \mathrm{C}$ solution NMR spectra at ambient temperature corresponds neither to the solid-state structure nor to a fully dynamic situation. Most striking is that two sets of signals of equal intensity are observed in the ${ }^{1} \mathrm{H}$ NMR spectrum for the OiPr groups and the $\mathrm{CH}$ protons of the cyclobutyl groups. The inequivalence of the OiPr groups indicates that either the inversion symmetry is lifted in solution or free rotation of the OiPr groups is restricted. On the other hand, the appearance of (only) two sets of cyclobutyl signals points to intramolecular ligand exchange processes. Both are common phenomena for Ti oxo clusters in solution. $^{35}$

We have shown previously that reaction of $\mathrm{Ti}(\mathrm{OiPr})_{4}$ with an equimolar amount of phthalic anhydride resulted in transfer of an OiPr group from the metal to one carbonyl group of the anhydride and coordination of the thus formed phthalic monoester to titanium to give $\mathrm{Ti}_{2}(\mathrm{OiPr})_{6}\left(\mathrm{OOC}-\mathrm{C}_{6} \mathrm{H}_{4}-\mathrm{COO}^{\mathrm{i}} \mathrm{Pr}\right)_{2}(\mathrm{iPrOH}) .{ }^{15}$ In the analogous reaction of $\mathrm{Ti}(\mathrm{OiPr})_{4}$ with maleic anhydride we now isolated a small proportion of $\mathrm{Ti}_{6} \mathrm{O}_{3}(\mathrm{OiPr})_{14}(\mathrm{OOC}-\mathrm{CH}=\mathrm{CH}$ $\mathrm{COO})_{2}$ (2) (denoted as $\mathrm{Ti}_{6} \mathrm{O}_{3}(\mathrm{OR})_{14}\left(\mathrm{OOCR}^{\prime}\right)_{4}$ in Scheme 1 for comparison with monocarboxylate ligands). This compound was almost certainly formed by the unintentional introduction of moisture in the system. We nevertheless report the structure of 2 here, because it nicely complements the structural series of known $\mathrm{Ti}_{6}$ clusters.

Type II $\mathrm{Ti}_{6} \mathrm{O}_{4}(\mathrm{OR})_{12}\left(\mathrm{OOCR}^{\prime}\right)_{4}$ clusters consist of two $\mathrm{Ti}_{3} \mathrm{O}(\mathrm{OR})_{6}{ }^{-}$ $\left(\mathrm{OOCR}^{\prime}\right)_{2}$ units (with $\mathrm{Ti}_{3} \mathrm{O}(\mathrm{OR})_{2}$ cores) which are connected by two $\mu_{3}-\mathrm{O}$. The building blocks of cluster 2 are the same $\mathrm{Ti}_{3} \mathrm{O}(\mathrm{OR})_{2}$ units, but connected by one $\mu_{2}-\mathrm{O}$ and two bridging dicarboxylate ligands. The structure of 2 (Fig. 2) can thus formally (!) be derived from the $\mathrm{Ti}_{6} \mathrm{O}_{4}$ cluster type by removing one $\mu_{3}-\mathrm{O}$ between the $\mathrm{Ti}_{3} \mathrm{O}(\mathrm{OR})_{2}$ units and replacing the second $\mu_{3}-\mathrm{O}$ by a $\mu_{2}-\mathrm{O}$ (compare Schemes 1 and 2). Charges and coordination sites are compensated by additional carboxylate groups. The substitution pattern of the bystander ligands in the $\mathrm{Ti}_{3} \mathrm{O}$ units of 2 is essentially the same as in $\mathrm{Ti}_{3} \mathrm{O}(\mathrm{OiPr})_{8}(\mathrm{OOCPh})_{2}{ }^{36}$ and $\mathrm{Ti}_{3} \mathrm{O}\left(\mathrm{OCH}_{2} \mathrm{CMe}_{3}\right)_{8}(\mathrm{OOCH})_{2} \cdot{ }^{5}$ Another way of looking at the structure of 2 therefore is that two such $\mathrm{Ti}_{3} \mathrm{O}$ clusters are bridged by a $\mu_{2}-\mathrm{O}(\mathrm{O} 3)$, where the $\mu_{2}-\mathrm{O}$ replaces a terminal OR ligand in each $\mathrm{Ti}_{3} \mathrm{O}$ cluster unit (see Discussion section).

One $\mathrm{Ti}$ atom in each $\mathrm{Ti}_{3} \mathrm{O}$ unit ( $\mathrm{Ti} 3$ and Ti6) is 5-coordinate, as in the reference $\mathrm{Ti}_{3} \mathrm{O}$ structures. Interestingly, the 5-coordinate $\mathrm{Ti}$ atoms are in geometrically different positions: in one unit (Ti1-Ti3) this is Ti3, bonded to the bridging oxygen $\mathrm{O} 3$, and in the second (Ti4-Ti6) Ti6 which is only bridged to one of its neighbors by a $\mu_{2}$-OR group. Correspondingly, the bridging $\mathrm{O} 3$ atom is closer to the 5-coordinate $\mathrm{Ti}$ atom (Ti3-O3 1.780(2) $\AA$ ) than to Ti4 (Ti4-O3 1.849(2) $\AA$ ), and the Ti-O distances between the $\mu_{3}$-oxygens $\mathrm{O} 1$ and $\mathrm{O} 2$ and the 5-coordinate Ti atoms (Ti3-O1 1.860(2), Ti6-O2 1.844(3) ̊) are shorter than to the 6-coordinate ones (1.979(2)-2.005(3) А).

Because 2 has no molecular symmetry, fourteen different groups of signals of the OiPr groups are expected in the ${ }^{1} \mathrm{H}$ NMR spectrum if the structure is static in solution. Although only four groups can be clearly resolved and the other ten groups only give a broad range of signals in the $\mathrm{CH}_{3}$ region of

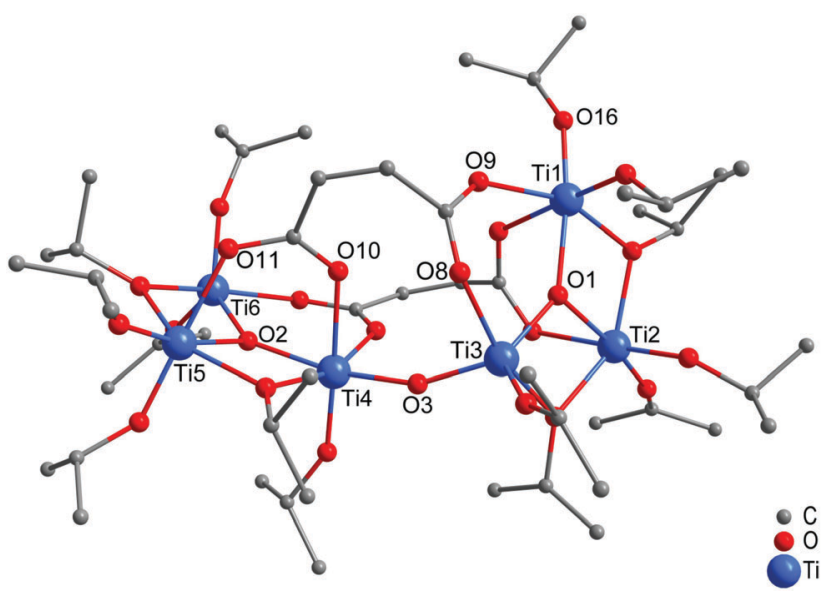

Fig. 2 Molecular structure of $\mathrm{Ti}_{6} \mathrm{O}_{3}(\mathrm{OiPr})_{14}(\mathrm{OOC}-\mathrm{CH}=\mathrm{CH}-\mathrm{COO})_{2}$ (2). Selected bond distances [Å] and angles [ $\left.{ }^{\circ}\right]$ : Ti1-O1 1.979(2), Ti2-O1 1.981(2), Ti3-O1 1.860(2), Ti4-O2 1.981(2), Ti5-O2 2.005(3), Ti6-O2 1.844(3), Ti3-O3 1.780(2), Ti4-O3 1.849(2). Ti1-O1-Ti3 144.5(1), Ti2-O1-Ti3 107.4(1), Ti1-O1-Ti2 105.3(1), Ti4-O2-Ti6 144.1(1), Ti5-O2-Ti6 107.0(1), Ti4-O2-Ti5 104.3(1), Ti3-O3-Ti4 156.6(1). 
the spectrum this appears to be the case. The $\mathrm{CH}$ is also not resolved. An assignment of the signals to specific OiPr groups is therefore not possible.

\section{Discussion}

Various types of carboxylate-substituted titanium oxo clusters have been isolated from reactions of titanium alkoxides with carboxylic acids. Clusters of a particular composition and structure are reproducibly formed, if the precursors and reaction conditions stay meticulously the same. While the structure of a given cluster can be rationalized, as discussed in the Introduction, it is currently not possible to predict which cluster type will be formed in a particular reaction environment. This is due to the fact that substitution and condensation reactions compete with each other and the relative rates of both reactions are influenced by a number of parameters, among them the electronic and steric properties of the groups $\mathrm{R}$ and $\mathrm{R}^{\prime}$ and the $\mathrm{Ti}(\mathrm{OR})_{4} / \mathrm{R}^{\prime} \mathrm{COOH}$ ratio. ${ }^{37}$ Furthermore, the reactions cannot be monitored in situ, because the IR and NMR spectra are largely uninformative. The isolation of a specific cluster from a reaction mixture (possibly containing different cluster species) could therefore also be due to a higher crystallization tendency.

However, comparative analysis of different cluster structures may give clues on how the structures develop during the reactions. We have discussed in a previous article ${ }^{33}$ that stable $\mathrm{Ti}_{3} \mathrm{O}(\mathrm{OR})_{8}\left(\mathrm{OOCR}^{\prime}\right)_{2}$ clusters are apparently only obtained if the groups $\mathrm{R}$ or $\mathrm{R}^{\prime}$ are bulky. The occurrence of $\mathrm{Ti}_{3} \mathrm{O}$ units in the majority of $\mathrm{Ti}$ oxo clusters with $d_{\mathrm{c}} \leq 1$ indicates that $\mathrm{Ti}_{3} \mathrm{O}$ clusters are formed early in the reactions and serve - if not stabilized by bulky groups - as building blocks for the thermodynamically favored products $\mathrm{Ti}_{6} \mathrm{O}_{6}(\mathrm{OR})_{6}\left(\mathrm{OOCR}^{\prime}\right)_{6}$ $\left(=\left[\mathrm{TiO}(\mathrm{OR})\left(\mathrm{OOCR}^{\prime}\right)\right]_{6}\right)$ and $\mathrm{Ti}_{8} \mathrm{O}_{8}\left(\mathrm{OOCR}^{\prime}\right)_{16}\left(=\left[\mathrm{TiO}\left(\mathrm{OOCR}^{\prime}\right)_{2}\right]_{8}\right)$. The other structurally characterized Ti oxo clusters are possibly snapshots for intermediate stages.

The series of clusters $\mathrm{Ti}_{6} \mathrm{O}_{4}(\mathrm{OR})_{8}\left(\mathrm{OOCR}^{\prime}\right)_{8}, \mathrm{Ti}_{6} \mathrm{O}_{5}(\mathrm{OiBu})_{6}{ }^{-}$ $(\mathrm{OOC} t \mathrm{Bu})_{8}{ }^{16}$ and $\mathrm{Ti}_{6} \mathrm{O}_{6}(\mathrm{OR})_{2}\left(\mathrm{OOCR}^{\prime}\right)_{10}$ (1) shows how condensation can proceed (increasing $d_{\mathrm{c}}$ ) structurally without greatly affecting the cluster core (Scheme 3). In going from the $\mathrm{Ti}_{6} \mathrm{O}_{4}$ to the $\mathrm{Ti}_{6} \mathrm{O}_{5}$ cluster, two terminal OR groups are replaced by a $\mu_{2}-\mathrm{O}$. This corresponds to a condensation process. Since this replacement does neither affect the charge balance nor the number of occupied coordination sites, no modification of the ligand sphere is necessary. Only the core of the $\mathrm{Ti}_{6} \mathrm{O}_{5}$ cluster is twisted compared with that of $\mathrm{Ti}_{6} \mathrm{O}_{4}$ due to the additional $\mu_{2}-\mathrm{O}$ bridge connecting the two $\mathrm{Ti}_{3} \mathrm{O}$ units. In going from the $\mathrm{Ti}_{6} \mathrm{O}_{4}$ to the $\mathrm{Ti}_{6} \mathrm{O}_{6}$ cluster, two $\mu_{2}$-OR groups are replaced by two $\mu_{2}-\mathrm{O}$. This implicates some modifications of the ligand sphere, as discussed above. Since additional carboxylate ligands are required, $d_{\mathrm{s}}$ also increases. Note that this discussion only refers to the development of the structure which not necessarily mirrors a reaction pathway from one cluster to another.

The structures of $\mathrm{Ti}_{3} \mathrm{O}(\mathrm{OR})_{8}\left(\mathrm{OOCR}^{\prime}\right)_{2}, \mathrm{Ti}_{6} \mathrm{O}_{3}(\mathrm{OR})_{14}\left(\mathrm{OOCR}^{\prime}\right)_{4}$ and $\mathrm{Ti}_{6} \mathrm{O}_{4}(\mathrm{OR})_{12}\left(\mathrm{OOCR}^{\prime}\right)_{4}$ (type II) can similarly be interrelated (Scheme 4). $\mathrm{Ti}_{6} \mathrm{O}_{3}(\mathrm{OR})_{14}(\mathrm{OOCR})_{4}$ is structurally derived from a formal condensation of two $\mathrm{Ti}_{3} \mathrm{O}$ clusters. The structure of $\mathrm{Ti}_{6} \mathrm{O}_{3}(\mathrm{OR})_{14}(\mathrm{OOCR})_{4}$ can similarly be converted into that of $\mathrm{Ti}_{6} \mathrm{O}_{4}(\mathrm{OR})_{12}\left(\mathrm{OOCR}^{\prime}\right)_{4}$ by intramolecular condensation of two OR groups with concomitant conversion of $\mu_{2}-\mathrm{O}$ into $\mu_{3}-\mathrm{O}$, by which all $\mathrm{Ti}$ atoms become 6-coordinate. Note again that this only a structural discussion, and formation of the clusters may proceed differently, especially in the case of 2 , where a dicarboxylate group is involved, rather than two monocarboxylate ligands.

\section{Experimental}

\section{General}

All experiments were carried out under Ar atmosphere using standard Schlenk techniques. Ti(OiPr $)_{4}$ was obtained from ABCR. All solvents used for NMR spectroscopy (Eurisotop) were degassed prior to use and stored over molecular sieve. ${ }^{1} \mathrm{H}$ and ${ }^{13} \mathrm{C}$ solution NMR spectra were recorded on a Bruker AVANCE $250\left(250.13 \mathrm{MHz}\left[{ }^{1} \mathrm{H}\right], 62.86 \mathrm{MHz}\left[{ }^{13} \mathrm{C}\right]\right)$ equipped with a $5 \mathrm{~mm}$ inverse-broadband probe head and a $z$-gradient unit.

\section{Synthesis of $\mathrm{Ti}_{6} \mathrm{O}_{6}(\mathrm{OiPr})_{2}\left(\mathrm{OOCC}_{4} \mathrm{H}_{7}\right)_{10}, 1 \mathrm{a}$}

$\mathrm{Ti}(\mathrm{OiPr})_{4}(0.31 \mathrm{ml}, 1 \mathrm{mmol})$ was slowly added to $0.38 \mathrm{ml}$ (4 mmol) of cyclobutane carboxylic acid under stirring. A clear solution was obtained of which crystals of 1a were obtained after 3 weeks. Yield $80 \mathrm{mg}(32 \%) .{ }^{1} \mathrm{H} \mathrm{NMR}\left(\mathrm{CDCl}_{3}, 250 \mathrm{MHz}\right)$ $\delta(\mathrm{ppm}) 1.22$ (d, $\left.J=6.28 \mathrm{~Hz}, 6 \mathrm{H}, \mathrm{CHCH}_{3}\right), 1.31(\mathrm{~d}, J=6.12 \mathrm{~Hz}, 6 \mathrm{H}$, $\left.\mathrm{CHCH}_{3}\right), 1.73-2.05\left(\mathrm{~m}, 20 \mathrm{H}, \mathrm{CH}_{2} \mathrm{CH}_{2} \mathrm{CH}_{2}\right), 2.06-2.50(\mathrm{~m}, 40 \mathrm{H}$, $\mathrm{CH}_{2} \mathrm{CH}$ ), 2.95-3.11 (m, 5H, $\mathrm{CHCH}_{2}$ ), 3.14-3.33 (m, 5H, $\mathrm{CHCH}_{2}$ ),
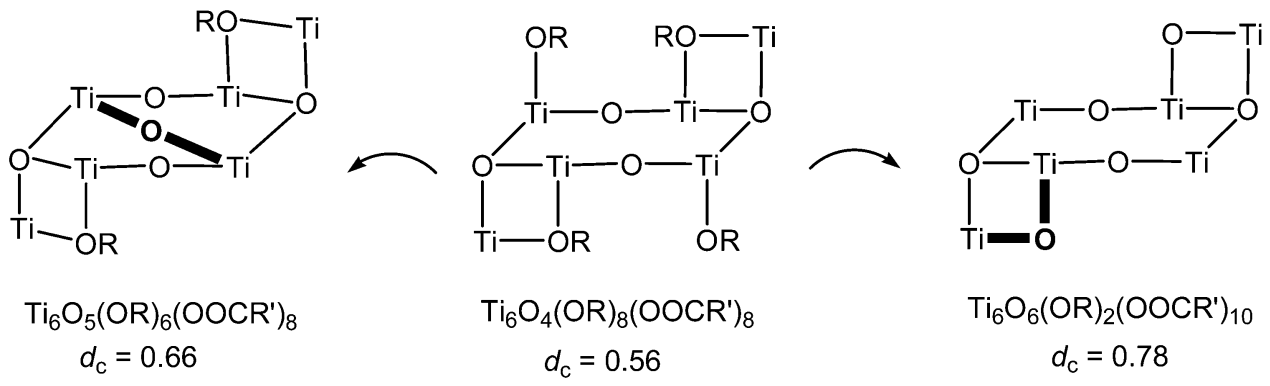
$\mathrm{Ti}_{6} \mathrm{O}_{6}(\mathrm{OR})_{2}\left(\mathrm{OOCR}^{\prime}\right)_{10}$ $d_{\mathrm{c}}=0.78$

Scheme 3 Interrelation of the cluster core structures of $\mathrm{Ti}_{6} \mathrm{O}_{5}$ and $\mathrm{Ti}_{6} \mathrm{O}_{6}$ with that of $\mathrm{Ti}_{6} \mathrm{O}_{4}$. The new groups/bonds are drawn in bold. The conformation of the cluster cores are drawn to emphasize structural similarities to the clusters in Schemes 1 and 2. 

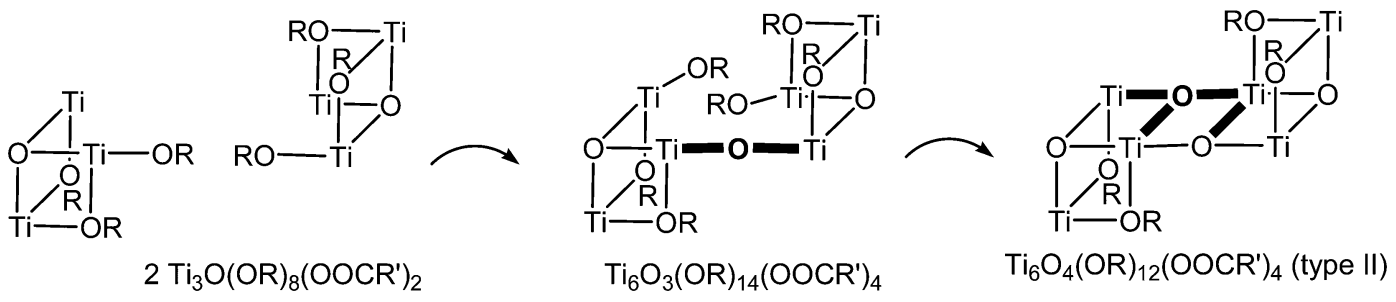

Scheme 4 Interrelation of the cluster core structures of $\mathrm{Ti}_{3} \mathrm{O}, \mathrm{Ti}_{6} \mathrm{O}_{3}$ and $\mathrm{Ti}_{6} \mathrm{O}_{4}$ (type II). The new bonds/groups are drawn in bold. The conformation of the cluster cores are drawn to emphasize structural similarities to the clusters in Schemes 1 and 2.

Table 1 Crystal data, data collection parameters and refinement details

\begin{tabular}{|c|c|c|c|}
\hline & 1a & $1 \mathrm{~b}$ & 2 \\
\hline$M_{\mathrm{r}}$ & 1490.6 & 1232.3 & 1390.7 \\
\hline Crystal system & Triclinic & Triclinic & Triclinic \\
\hline$a(\AA)$ & $9.6136(4)$ & $9.363(1)$ & $12.5972(3)$ \\
\hline$b(\AA)$ & $12.9095(7)$ & $11.467(2)$ & $15.6563(3)$ \\
\hline$c(\AA)$ & $13.5706(7)$ & $12.838(2)$ & $19.9053(4)$ \\
\hline$\left.y 0^{\circ}\right)$ & $105.180(2)$ & $75.625(7)$ & $83.588(1)$ \\
\hline$V\left(\AA^{3}\right)$ & $1601.5(1)$ & $1277.0(4)$ & $3655.3(1)$ \\
\hline$Z$ & 1 & 1 & 2 \\
\hline$D_{x}\left(\mathrm{~g} \mathrm{~cm}^{-3}\right)$ & 1.546 & 1.602 & 1.264 \\
\hline$T(\mathrm{~K})$ & 100 & 100 & 295 \\
\hline$\mu\left(\mathrm{mm}^{-1}\right)$ & 0.797 & 0.981 & 0.690 \\
\hline Crystal size $(\mathrm{mm})$ & $0.2 \times 0.1 \times 0.05$ & $0.33 \times 0.31 \times 0.29$ & $0.30 \times 0.27 \times 0.20$ \\
\hline Weighting scheme ${ }^{a}$ & $x=0.06587, y=0.7700$ & $x=0.0352, y=0$ & $x=0.0886, y=2.9622$ \\
\hline$\delta \rho_{\max }, \delta \rho_{\min }\left(\mathrm{e} \AA^{-3}\right)$ & $0.912,-0.429$ & $0.904,-0.914$ & $0.969,-0.406$ \\
\hline
\end{tabular}

$4.82\left(\mathrm{~m}, J=6.12 \mathrm{~Hz}, 1 \mathrm{H}, \mathrm{CHCH}_{3}\right), 5.00\left(\mathrm{~m}, J=6.28 \mathrm{~Hz}, 1 \mathrm{H}, \mathrm{CHCH}_{3}\right)$. ${ }^{13} \mathrm{C}\left\{{ }^{1} \mathrm{H}\right\}$ NMR $\left(\mathrm{CDCl}_{3}, 62.9 \mathrm{MHz}\right) \delta(\mathrm{ppm}) 18.24,18.35,18.52,18.72$ $\left(\mathrm{CH}_{2} \mathrm{CH}_{2} \mathrm{CH}_{2}\right), 21.79,24.38\left(\mathrm{CHCH}_{3}\right), 25.14,25.24,25.29,25.40$, 25.46, 25.57, 25.61, $25.70\left(\mathrm{CH}_{2} \mathrm{CH}\right), 37.74,38.37,39.47,40.00$, 40.14, 40.24 (CHCOO), 67.26, 77.19, $81.47\left(\mathrm{CHMe}_{2}\right)$, 180.80, 182.88, 184.38, 185.18, 185.78, 186.80 (COO).

\section{Synthesis of $\mathrm{Ti}_{6} \mathrm{O}_{3}(\mathrm{OiPr})_{14}(\mathrm{OOC}-\mathrm{CH}=\mathrm{CH}-\mathrm{COO})_{2}, 2$}

$\mathrm{Ti}(\mathrm{OiPr})_{4}(8.8 \mathrm{ml}, 30.3 \mathrm{mmol})$ was added to $2.96 \mathrm{~g}(30.1 \mathrm{mmol})$ of maleic anhydride in $9.3 \mathrm{ml}$ of iPrOH. Crystals of 2 were obtained after 16 weeks at room temperature. Yield $200 \mathrm{mg}$ (3\%). ${ }^{1} \mathrm{H}$ NMR $\left(\mathrm{C}_{6} \mathrm{D}_{6}\right) \delta 1.34-1.54\left(\mathrm{~m}, 60 \mathrm{H}, \mathrm{CH}_{3}\right), 1.63(\mathrm{~d}, J=6.22$ $\left.\mathrm{Hz}, 6 \mathrm{H}, \mathrm{CH}_{3}\right), 1.73\left(\mathrm{~d}, J=6.26 \mathrm{~Hz}, 6 \mathrm{H}, \mathrm{CH}_{3}\right), 1.92(\mathrm{~d}, J=6.26 \mathrm{~Hz}$, $\left.6 \mathrm{H}, \mathrm{CH}_{3}\right), 1.94\left(\mathrm{~d}, J=6.22 \mathrm{~Hz}, 6 \mathrm{H}, \mathrm{CH}_{3}\right), 5.00-5.40(\mathrm{~m}, 14 \mathrm{H}, \mathrm{CH})$, $6.06(\mathrm{~s}, 4 \mathrm{H},=\mathrm{CH}) .{ }^{13} \mathrm{C}\left\{{ }^{1} \mathrm{H}\right\} \mathrm{NMR}\left(\mathrm{C}_{6} \mathrm{D}_{6}\right) \delta 24.47,24.84,24.90$, 25.10, 25.44, 25.60, 25.71, 25.80, 25.90, 26.04, $26.11\left(\mathrm{CH}_{3}\right)$, 76.58, 77.25, 77.86, 78.40, 78.81, 79.28, $79.35\left(\mathrm{CHMe}_{2}\right), 134.41$ (= $\mathrm{CH}), 171.45,173.21$ (COO).

\section{X-ray structure analyses}

Crystallographic data were collected on a Bruker AXS SMART APEX II four-circle diffractometer with $\kappa$-geometry using $\mathrm{MoK}_{\alpha}$ $(\lambda=0.71073 \AA)$ radiation. The data were corrected for polarization and Lorentz effects, and an empirical absorption correction (SADABS) was employed. The cell dimensions were refined with all unique reflections. SAINT PLUS software (Bruker Analytical X-ray Instruments, 2007) was used to integrate the frames. Symmetry was then checked with the program PLATON. ${ }^{38}$

The structures were solved by charge flipping (JANA2006). Refinement was performed by the full-matrix least-squares method based on $F^{2}$ (SHELXL97) with anisotropic thermal parameters for all non-hydrogen atoms. Hydrogen atoms were inserted in calculated positions and refined riding with the corresponding atom. Crystal data, data collection parameters and refinement details are listed in Table 1.

\section{Conflicts of interest}

There are no conflicts to declare.

\section{References}

1 Review: U. Schubert, J. Mater. Chem., 2005, 15, 3701-3715. 
2 Review: L. Rozes and C. Sanchez, Chem. Soc. Rev., 2011, 40, 1006-1030.

3 P. Papiernik, L. G. Hubert-Pfalzgraf, J. Vaissermann and M. C. H. B. Goncalves, J. Chem. Soc., Dalton Trans., 1998, 2285-2287.

4 T. J. Boyle, T. M. Alam and C. J. Tafoya, Inorg. Chem., 1998, 37, 5588-5594.

5 T. J. Boyle, R. P. Tyner, T. M. Alam, B. L. Scott, J. W. Ziller and B. G. Potter, Jr., J. Am. Chem. Soc., 1999, 121, 12104-12112.

6 A. Pandey, V. D. Gupta and H. Nöth, Eur. J. Inorg. Chem., 2000, 1351-1357.

7 A. Rammal, F. Brisach and M. Henry, C. R. Chim., 2002, 5, 59-66.

8 P. S. Ammala, S. R. Batton, C. M. Kepert, L. Spiccia, A. M. Van der Bergen and B. O. West, Inorg. Chim. Acta, 2003, 353, 75-81.

9 P. Piszczek, A. Grodzicki, M. Richert and A. Wojtczak, Inorg. Chim. Acta, 2004, 357, 2769-2775.

10 R. Sui, P. A. Charpentier, A. S. Rizkalla and M. C. Jennings, Acta Crystallogr., 2006, E62, m373-m375.

11 P. Piszczek, M. Richert and A. Wojtczak, Polyhedron, 2008, 27, 602-608.

12 P. Piszczek, M. Richert, A. Radtke, T. Muziol and A. Wojtczak, Polyhedron, 2009, 28, 3872-3880.

13 J. B. Benedict and P. Coppens, J. Am. Chem. Soc., 2010, 132, 2938-2944.

14 G. A. Seisenbaeva, E. Ilina, S. Håkansson and V. G. Kessler, J. Sol-Gel Sci. Technol., 2010, 55, 1-8.

15 M. Czakler, C. Artner and U. Schubert, Eur. J. Inorg. Chem., 2012, 3485-3489.

16 P. Piszczek, A. Radtke, T. Muziol, M. Richert and J. Chojnacki, Dalton Trans., 2012, 41, 8261-8269.

17 A. Radtke, P. Piszczek, T. Muziol and A. Wojtczak, Inorg. Chem., 2014, 53, 10803-10810.

18 Y. Fan, Y. Cui, G.-D. Zou, R.-H. Duan, X. Zhang, Y.-X. Dong, H.-T. Lv, J.-T. Cao and Q.-S. Jing, Dalton Trans., 2017, 46, 8057-8064.

19 C. Artner, A. Koyun, M. Czakler and U. Schubert, Eur. J. Inorg. Chem., 2014, 5008-5014.
20 I. Gautier-Luneau, A. Mosset and J. Galy, Z. Kristallogr., 1987, 180, 83-95.

21 S. Doeuff, Y. Dromzee, F. Taulelle and C. Sanchez, Inorg. Chem., 1989, 28, 4439-4445.

22 I. Laaziz, A. Larbot, C. Guizard, J. Durand, L. Cot and J. Joffre, Acta Crystallogr., Sect. C: Cryst. Struct. Commun., 1990, 46, 2332-2334.

23 U. Schubert, E. Arpac, W. Glaubitt, A. Helmerich and C. Chau, Chem. Mater., 1992, 4, 291-295.

24 B. Moraru, N. Hüsing, G. Kickelbick, U. Schubert, P. Fratzl and H. Peterlik, Chem. Mater., 2002, 14, 2732-2740.

25 G. Kickelbick, D. Holzinger, C. Brick, G. Trimmel and E. Moons, Chem. Mater., 2002, 14, 4382-4389.

26 Y. Gao, F. R. Kogler, H. Peterlik and U. Schubert, J. Mater. Chem., 2006, 16, 3268-3276.

27 P. Heinz, M. Puchberger, M. Bendova, S. O. Baumann and U. Schubert, Dalton Trans., 2010, 39, 7640-7644.

28 S. Doeuff, Y. Dromzee and C. Sanchez, C. R. Seances Acad. Sci., Ser. 2, 1989, 308, 1409-1412.

29 X. Lei, M. Shang and T. P. Fehlner, Organometallics, 1996, 15, 3779-3781.

30 X. Lei, M. Shang and T. P. Fehlner, Organometallics, 1997, 16, 5289-5301.

31 N. Steunou, F. Robert, K. Boubekeur, F. Ribot and C. Sanchez, Inorg. Chim. Acta, 1998, 279, 144-151.

32 I. Mijatovic, G. Kickelbick and U. Schubert, Eur. J. Inorg. Chem., 2001, 1933-1935.

33 M. Czakler and U. Schubert, Inorg. Chim. Acta, 2018, 471, 567-569.

34 C. Artner, M. Czakler and U. Schubert, Chem. - Eur. J., 2014, 493-498.

35 U. Schubert, Coord. Chem. Rev., 2017, 350, 61-67.

36 I. Mijatovic, G. Kickelbick, M. Puchberger and U. Schubert, New J. Chem., 2003, 27, 3-5.

37 U. Schubert, J. Mater. Chem., 2005, 15, 3701-3715, and references cited therein.

38 G. M. Sheldrick, SHELXS-97, Program for Crystal Structure Determination, University of Göttingen, Göttingen, Germany, 1997. 